\title{
Franchise extension and fiscal structure in the UK 1820-1913: a new test of the Redistribution Hypothesis
}

\author{
Toke S. Aidt ${ }^{1,2}\left(\right.$ D $\cdot$ Stanley L. Winer ${ }^{2,3}\left(\mathbb{D} \cdot\right.$ Peng Zhang $^{4}$
}

Received: 19 July 2021 / Accepted: 29 September 2021 / Published online: 9 November 2021

(c) The Author(s) 2021

\begin{abstract}
The Redistribution Hypothesis predicts that franchise extension causes an increase in state-sponsored redistribution. We test this hypothesis by considering the relationship between franchise extension and selected aspects of fiscal structure at both central and local government levels in the UK from 1820 to 1913 . We do so without imposing a priori restrictions on the direction of causality using a novel method for causal investigation of non-experimental data proposed by Hoover (2001). This method is based on tests for structural breaks in the conditional and marginal distributions of the franchise and fiscal structure time series preceded by a detailed historical narrative analysis. We do not find compelling evidence supporting the Redistribution Hypothesis.
\end{abstract}

Keywords Franchise extension · Redistribution · Democratization · Causality · Structural breaks $\cdot$ Central government $\cdot$ Historical narrative

JEL Classification D72 $\cdot$ D78 $\cdot \mathrm{H} 50 \cdot \mathrm{H} 72 \cdot \mathrm{N} 43$

Equal contribution of the three authors.

This research was made possible by a grant from the Keynes Fund (Cambridge) (JHOA). Constructive comments from Kevin Hoover, Roger Congleton, Jac Heckelman, Tom Groll, and Jean Lacroix and from participants in the European Public Choice Society meeting in Rome 2018, the EEA/ES meeting in Manchester 2019, the International Institute of Public Finance Congress 2019 in Glasgow, the Canadian Economics Association Meetings, Banff 2019 and in seminars at University of York, Carleton University, Cambridge, Wake Forest University and University of West Virginia are greatly appreciated.

Toke S. Aidt

tsa23@econ.cam.ac.uk

Extended author information available on the last page of the article 


\section{Introduction}

Almost all political economy models of voting and public policy contain within them the Redistribution Hypothesis - the prediction that enlargement of the voting franchise to poorer citizens will lead to demands for more state-sponsored redistribution which are at least partly satisfied by politicians elected on the basis of the broader suffrage. The Redistribution Hypothesis is most clearly expressed in the work of Meltzer and Richard (1981) and features prominently both in Acemoglu and Robinson (2000)'s theory of franchise extension and in Lindert (2004a)'s historical analysis of public sector growth. ${ }^{1}$ However, it has proved difficult to establish empirically a causal, positive relationship between extension of voting rights and the extent of redistribution through the public sector. One reason is that causality may, in fact, run the other way if redistributive pressures are the cause of franchise extensions. The main contribution of this paper is to test the Redistribution Hypothesis with British time series data covering the long nineteenth century using an alternative statistical method and in that way to provide new evidence about this fundamental question in political economy. The method, detailed in Hoover (2001), is based on a combination of detailed historical narrative analysis and study of the pattern of structural breaks in the conditional and marginal distributions of the time series representing the franchise and fiscal structure. Unlike commonly used single-equation structural breaks methods, by studying both the conditional and marginal distributions, this multi-equation method does not impose restrictions on the direction of causality a priori. We apply the method to study local and central government public finances in the UK from 1820 to 1913.

The dominant approach in the empirical literature on the Redistribution Hypothesis is to investigate cross-country panel data and to test whether the conditional mean of the relevant fiscal policy variables - total spending or taxation relative to GDP, measures of tax or expenditure structure, and marginal tax rates-react in the predicted way to episodes of democratization. Acemoglu et al. (2015, p. 1885) provide a comprehensive survey of this literature and conclude that "democracy does not lead to a uniform decline in post-tax inequality, but can result in changes in fiscal redistribution and economic structure that have ambiguous effects on inequality". Some of these fiscal adjustments are consistent with the Redistribution Hypothesis (e.g. Lindert (1994), Husted and Kenny (1997), Kenny and Winer (2006), Aidt et al. (2006) or Kim (2007)) but others are not (e.g. Aidt and Jensen (2009b), Mares and Queralt (2015) or Profeta et al. (2013)) or only conditionally (Boix 2001, 2003; Aidt and Jensen 2009a). Moreover, Dorsch and Maarek (2019) show that democratization, in fact, drives extreme income distributions to the middle ground, that is, the effect depends on the level of inequality prior to reform.

The main weakness of the empirical literature on the Redistribution Hypothesis is that it struggles, with a few exceptions such as Aidt and Jensen (2013) and Cascio and Washington (2014), to isolate causal effects. While interesting and suggestive

\footnotetext{
1 Winer (2019) provides an upto date survey of the related literature, and Harms and Zink (2003) review theoretical reasons why there are limits to redistribution.
} 
correlations have been uncovered, they can only be given a causal interpretation when the assumption of conditional independence is tenable. The fact that the relationship between democratization and the evolution of the fiscal system is complex and interwoven with structural transformation, industrialization, urbanization and economic growth (e.g. Lindert 2004a, b) inevitably casts doubt on this assumption. While suffrage reforms may cause changes in the fiscal system, as hypothesized by Meltzer and Richard (1981) and integrated into the theory of franchise extension developed by Acemoglu and Robinson (2000) and Boix (2003), it is also possible that demands on the fiscal system-e.g. a desire to tap into tax sources that require a high degree of voluntary compliance which can be ensured by sharing voting rights-cause suffrage reforms. It is, of course, also possible that the two processes are caused by the same underlying forces, such as enlightenment and the spread of ideas about the value of a liberal political system and the benefit of state-sponsored social insurance, social welfare and progressive taxation or by war (Scheve and Stasavage 2016).

In this paper, we consider the issue of causality from a new perspective. In a sequence of papers (Hoover 1991; Hoover and Sheffrin 1992; Hoover and Siegler 2000) and in a subsequent book (Hoover 2001), Kevin Hoover and his co-authors develop the approach that we adopt. ${ }^{2}$ For simplicity, we refer to the approach as the Hoover approach but note that it is based on the foundation laid by Neftci and Sargent (1987), Simon and Iwasaki (1988) and others. The Hoover approach combines a detailed historical narrative with structural breaks econometrics in order to determine the causal order. The main innovation in the approach is to study the evolution over time of both the marginal and the conditional distributions involved, and to look for specific patterns of breaks in the underlying time series that then establish the causal order. The historical narrative provides an important cross-check on the tests for structural breaks - a break identified statistically when no relevant intervention can be identified historically may indicate statistical misspecification. This approach is a complement to quasi-experimental methods (Angrist and Pischke 2008) that can be used with long time series and is fundamentally different from the commonly used study of parameter stability in the conditional distribution of a time series before and after a contextual shock. These single-equation approaches aim at discriminating between particular models and to test a specific causal order. This is restrictive when the causal order is a priori unclear. By studying the properties of the marginal and the conditional distributions, the Hoover method is agnostic as to the causal order and allows a priori for the four logical possibilities: A causes B, B causes A, A and B are independent, and A and B are jointly determined. The method can uncover the direction of causality, but it cannot identify the size of any causal effect.

\footnotetext{
${ }^{2}$ Hoover (1991) studies the causal relationship between inflation and money growth (and finds that it is prices that cause money). Hoover and Sheffrin (1992) and Hoover and Siegler (2000) study the relationship between taxes and public spending for the federal government in the USA. They find two distinct causal patterns: Before the mid-1960s, taxes appear to cause spending, but afterwards taxes and spending are independent.
} 
We study central and local government in the UK between 1820 and 1913 for two particular reasons. First, in the UK, the franchise governing elections to the House of Commons was sequentially extended through three important and distinct reforms in 1832, 1867 and 1884, with the third Reform being the most substantial increasing the fraction of adult males with the right to vote by 78 percent. ${ }^{3}$ For local government in England and Wales - the Municipal Boroughs - the franchise was also extended in a sequence of reforms in 1869, 1878, 1882, 1888 and 1894. Unlike many other countries in Europe where democratic rights were extended to (almost) all males in one go, these sequential reforms make the UK an ideal testing ground for the Redistribution Hypothesis. Second, the Hoover approach requires long and reliable time series on both the franchise and fiscal variables related to redistribution which are available for the UK.

For the nexus between the fiscal system of the central government and the suffrage for the House of Commons, we find one instance in which the historical narrative of interventions to the franchise - specifically, the 3rd Reform Act 1884 - and the pattern of structural breaks are consistent with the Redistribution Hypothesis. However, this evidence concerns the effect of franchise reform on the expenditure size of government only, is not found in the tax size and is not robust to variations in the research design. We also find instances in which interventions to the fiscal system-in particular the fiscal rules laid down by William Gladstone in the 1850s and dismantled in the 1890s — and the pattern of structural breaks are consistent with the Redistribution Hypothesis, in the sense that these structural shifts in fiscal policy did not affect the franchise process, which was evidently independent of them. The result related to Gladstone's fiscal rules is robust to the choice of variables used to pre-filter the series, but, by itself, this result only identifies an important structural break in the public finances that is independent of the franchise process. For local government in England and Wales, we find evidence that the Municipal Franchise Act of 1869 may have had a causal impact on the tax structure-specifically, the share of property tax revenues-of the Municipal Boroughs. This causal order cannot, however, be confirmed by evidence from historically plausible interventions in the local fiscal system. Overall, then, we do not find compelling evidence in support of the Redistribution Hypothesis.

\section{The Hoover approach}

The Hoover approach to causality that we use to study the causal relationship between the extension of the franchise and aspects of fiscal structure consists of two steps. The first step is to construct a narrative of possible interventions in the suffrage and in the fiscal structure from the historical record. This is done prior to any statistical testing. The second step is to use statistical tests to find patterns of

\footnotetext{
${ }^{3}$ We do not include the 4th reform act in 1918 because it coincided with the end of World War I. This makes it impossible to disentangle the effect of war on the fiscal system on the one hand and the extension of suffrage on the other.
} 
structural breaks which, after comparison with the historical narrative as a check on the statistical analysis, are then used to draw causal inferences. In this section, we present the basic logic behind the second step. We return to the historical narrative in Sect. 3.

To begin, suppose we have two time series that measure the extension of the franchise $e$ and some aspect of the fiscal system $f$. With regard to the causal relationship between the two processes underlying the observed time series, there are four possibilities

$$
e \leftarrow f ; e \rightarrow f ; f \leftrightarrow e ; f \perp e,
$$

where the right and left arrows indicate direction of causality, $\leftrightarrow$ indicates mutual dependency and $\perp$ indicates independence. Now, consider the marginal and conditional distributions that make up the joint distribution $D(e, f)$ of the two series. This joint distribution can be written as the product of a conditional and a marginal distribution in two equivalent ways:

$$
D(f, e)=D(e) D(f \mid e)=D(f) D(e \mid f) .
$$

While the two factorizations are observationally equivalent, Hoover (2001) shows that breaks in the process governing the mean of $f$ will lead to one pattern of breaks in (or shifts in the mean of) these conditional and marginal distributions if the fiscal structure causes the franchise, and to a different pattern of breaks or shifts if the Redistribution Hypothesis is true and a break in the process for $e$ causes a break in the process governing $f$. By identifying structural breaks in the time series for $e$ and $f$, and then observing the pattern of breaks in the associated marginal and conditional distributions, it is possible to determine the direction of causality between them.

An example, following Hoover and Sheffrin (1992, p. 230), illustrates how causality may be determined. Since this argument may be unfamiliar to many readers, we summarize the example at length using our notation and context. The premise of the example is that $e$ causes $f$ in the sense that the value of $f$ depends on the value of $e$, but not vice versa (Hoover 2001, p. 59). For simplicity, we assume that the time series for $e$ and $f$ are normally, independently distributed processes. ${ }^{4}$ Combining these two assumptions, we can write the data generating processes as

$$
\begin{aligned}
& f=\alpha e+\epsilon ; \text { with } \epsilon \sim N\left(0, \sigma_{\epsilon}^{2}\right) \\
& e=\beta+\eta ; \text { with } \eta \sim N\left(0, \sigma_{\eta}^{2}\right),
\end{aligned}
$$

where $\operatorname{cov}(\epsilon, \eta)=0, E\left(\epsilon_{t}, \epsilon_{s}\right)=0, E\left(\eta_{t}, \eta_{s}\right)=0$, and $\alpha$ and $\beta$ are parameters. The reduced forms of Eqs. (2) and (3) which, along with the distributions of $\epsilon$ and $\eta$, describe the joint probability distribution $D(e, f)$ are:

\footnotetext{
${ }^{4}$ We omit time subscripts on the variables for simplicity.
} 
Table 1 Example: Using structural breaks to determine the causal order

\begin{tabular}{lcc}
\hline \hline Distribution & break in $\beta$ & break in $\alpha$ \\
\hline$D(f \mid e)=N\left(\alpha e, \sigma_{\epsilon}^{2}\right)$ & stable & break \\
$D(e)=N\left(\beta, \sigma_{\eta}^{2}\right)$ & break & stable \\
$D(e \mid f)=N\left(\frac{\alpha \sigma_{\eta}^{2} f+\beta \sigma_{\epsilon}^{2}}{\alpha^{2} \sigma_{\eta}^{2}+\sigma_{\epsilon}^{2}}, \cdot\right)$ & break & break \\
$D(f)=N(\alpha \beta, \cdot)$ & break & break \\
\hline \hline
\end{tabular}

Notes: The table is based on the assumption that $e$ causes $f$ and shows how an intervention is $e$ (column 1) or $f$ (column 2) is associated with a unique configuration of breaks

$$
\begin{gathered}
f=\alpha \beta+\alpha \eta+\epsilon \\
e=\beta+\eta .
\end{gathered}
$$

The joint distribution $D(e, f)$ is a multivariate normal with well-known form (see, for example, Mood and Graybill 1963, Chapter 9). Accordingly, we can use our knowledge of the functional form of the multivariate normal along with the decomposition in Eq. (1) to specify the following conditional and marginal distributions:

$$
\begin{gathered}
D(f \mid e)=N\left(\alpha e, \sigma_{\epsilon}^{2}\right) \\
D(e)=N\left(\beta, \sigma_{\eta}^{2}\right) \\
D(e \mid f)=N\left(\frac{\alpha \sigma_{\eta}^{2} f+\beta \sigma_{\epsilon}^{2}}{\alpha^{2} \sigma_{\eta}^{2}+\sigma_{\epsilon}^{2}}, \frac{\sigma_{\eta}^{2} \sigma_{\epsilon}^{2}}{\alpha^{2} \sigma_{\eta}^{2}+\sigma_{\epsilon}^{2}}\right) \\
D(f)=N\left(\alpha \beta, \alpha^{2} \sigma_{\eta}^{2}+\sigma_{\epsilon}^{2}\right) .
\end{gathered}
$$

Now, recall that the premise of the example is that $e$ causes $f$. If there is a break in the mean $(\beta)$ of the suffrage series in a given year, e.g. because a significant suffrage reform took place in that year, then the above equations indicate that all of $D(e)$, $D(e \mid f)$ and $D(f)$ break. But conditional on the franchise, the distribution $D(f \mid e)$ remains stable. That is, the distribution that corresponds to the true causal structure remains stable in the year where all the other distributions exhibit a structural break. Intuitively, since $e$ causes $f$ by assumption, controlling for changes in the suffrage process leaves the fiscal process unaffected. Analogously, and still assuming that $e$ causes $f$, the above equations indicate that a break in the mean $(\alpha)$ of the process governing $f$-as when, for example, there is a tax collection innovation that causes the size of the public sector to increase for reasons unrelated to $e$-leads to breaks in all of the distributions including $D(f \mid e)$, except that for the marginal distribution $D(e)$. The latter distribution remains stable in the year in which the other distributions break because, by assumption about the direction of causality, the marginal 
Table 2 How to determine the causal order from patterns of structural breaks

Table A

\begin{tabular}{|c|c|c|c|c|c|c|c|}
\hline & \multicolumn{3}{|c|}{$D(f)$} & & \multicolumn{3}{|c|}{$D(e)$} \\
\hline$D(f \mid e)$ & $\begin{array}{c}\text { Stable } \\
\text { Unstable }\end{array}$ & $\begin{array}{l}\text { Stable } \\
f \perp e \\
e \leftarrow f\end{array}$ & $\begin{array}{c}\text { Unstable } \\
e \rightarrow f \\
f \leftrightarrow e\end{array}$ & $D(e \mid f)$ & $\begin{array}{c}\text { Stable } \\
\text { Unstable }\end{array}$ & $\begin{array}{c}\text { Stable } \\
f \perp e \\
e \rightarrow f\end{array}$ & $\begin{array}{c}\text { Unstable } \\
e \leftarrow f \\
f \leftrightarrow e\end{array}$ \\
\hline
\end{tabular}

Notes: Panel A or B are used to draw conclusions about the causal order conditional on test A(i) or test B(i) having been passed. The arrows indicate the direction of causality and $\perp$ means that the two series are independent

distribution of $e$ does not depend on $f$. Again, we see that it is the distribution that reflects the true underlying causal structure that remains stable.

If in the presence of breaks in $e$, we observe that $D(f \mid e)$ remains stable, and if in the presence of breaks in $f$, we observe that $D(e)$ remains stable, we may conclude that there is evidence that $e$ causes $f$. Hence, the first decomposition of the joint distribution in Eq. (1), $D(f \mid e) \cdot D(e)$ is different from the second one, in that at least one of its two elements remain stable if $e$ causes $f$. But neither of the elements in the second decomposition remain stable in the face of these shocks. This is summarized in Table 1. We observe that we can learn whether the voting franchise causes redistribution from interventions in either the suffrage series or in the fiscal series. However, convincing evidence in favour of the Redistribution Hypothesis requires both, that is, that we can find years where the historical narrative indicates an intervention in the suffrage series (break in $\beta$ ) and the statistical tests indicate the pattern in column 1 of Table 1 and that we can find (other) years where the historical narrative indicates an intervention in the fiscal series (break in $\alpha$ ) and the statistical tests indicate the pattern in column 2 .

The case in which $f$ causes $e$ can be assessed in analogous fashion, with the opposite conclusion that one element in the second decomposition in Eq. (1) will remain "stable". If the processes are simultaneous, in the face of the two shocks considered all of the elements in the decompositions in Eq. (1) will, under one or the other shock, be unstable.

Adding this up, we can apply the following algorithm to locate years where the constellation of breaks in the marginal and conditional distributions of $e$ and $f$ enables us to draw inferences about the causal relationship between them:

Test A: (i) check that $D(e \mid f)$ and $D(e)$ break in year t; (ii) use Table 2A to check whether in year t, $D(f)$ and $D(f \mid e)$ are stable or not and draw the inference indicated.

Test B: (i) check that $D(f \mid e)$ and $D(f)$ break in year t; (ii) use Table 2B to check whether in year t, $D(e)$ and $D(e \mid f)$ are stable or not and draw the inference indicated.

An integral feature of the Hoover approach is that the statistical analysis should be preceded by a detailed analysis of the historical narrative. This provides 
non-statistical information about possible structural breaks which is used to assess, confirm or reject the outcome of the formal statistical analysis. A prerequisite for drawing causal inferences from test $\mathrm{A}$ and test $\mathrm{B}$ is that the historical narrative clearly indicates that there was an intervention in the suffrage (test A) or in the fiscal structure (test B) in year $t$ that is consistent with the historical facts. If not, no causal inference should be based on it.

\section{The historical narrative}

We now review the historical record to identify plausible candidates for structural breaks in the franchise rules and in the fiscal system. We focus on factual changes in rules or policy and our criteria are (i) the intervention has to be substantial and well documented in the historiography, (ii) for the fiscal system, the intervention has to have a direct impact on the fiscal system, i.e. we do not include non-fiscal changes in legislation or interventions affecting other levels of government, and (iii) for the franchise rules, the intervention has to affect who could vote in the relevant elections and under which conditions. We focus on the two main parts of the fiscal system in Britain in the long nineteenth century. The first part is the relationship between central government public finances and the suffrage rules for elections to the British House of Commons (1820-1913). The second part is the relationship between municipal public finances and the suffrage rules for municipal elections (1867-1912). The suffrage rules as well as the fiscal constraints operating in the two parts were fundamentally different.

\subsection{Historical narrative: the central government, 1820-1913}

Table 3 provides an overview of the major events that we view as plausible candidates for structural breaks in the rules governing election to the British House of Commons and in the central government's fiscal system.

\subsubsection{The suffrage rules for the house of commons}

Prior to 1832 , only a small fraction of the population could vote in elections to the House of Common and elections were often not contested. The Great Reform Act of 1832 introduced a limited property-based suffrage, with different property value thresholds in the borough and county constituencies, and redistributed seats from small "rotten" boroughs to the industrial cities in the Midlands and the North of England (Brock 1973). The consequence was to increase the male electorate from 2-3 percent to 4-6 percent of the total English population of 13 million (Cannon 1973).

The next franchise extension happened in 1867 (Smith 1966). The Second Reform Act granted the vote to all householders in the borough constituencies as well as to lodgers who paid rent of $£ 10$ a year or more, reduced the property threshold in the county constituencies and gave the vote to agricultural landowners and 


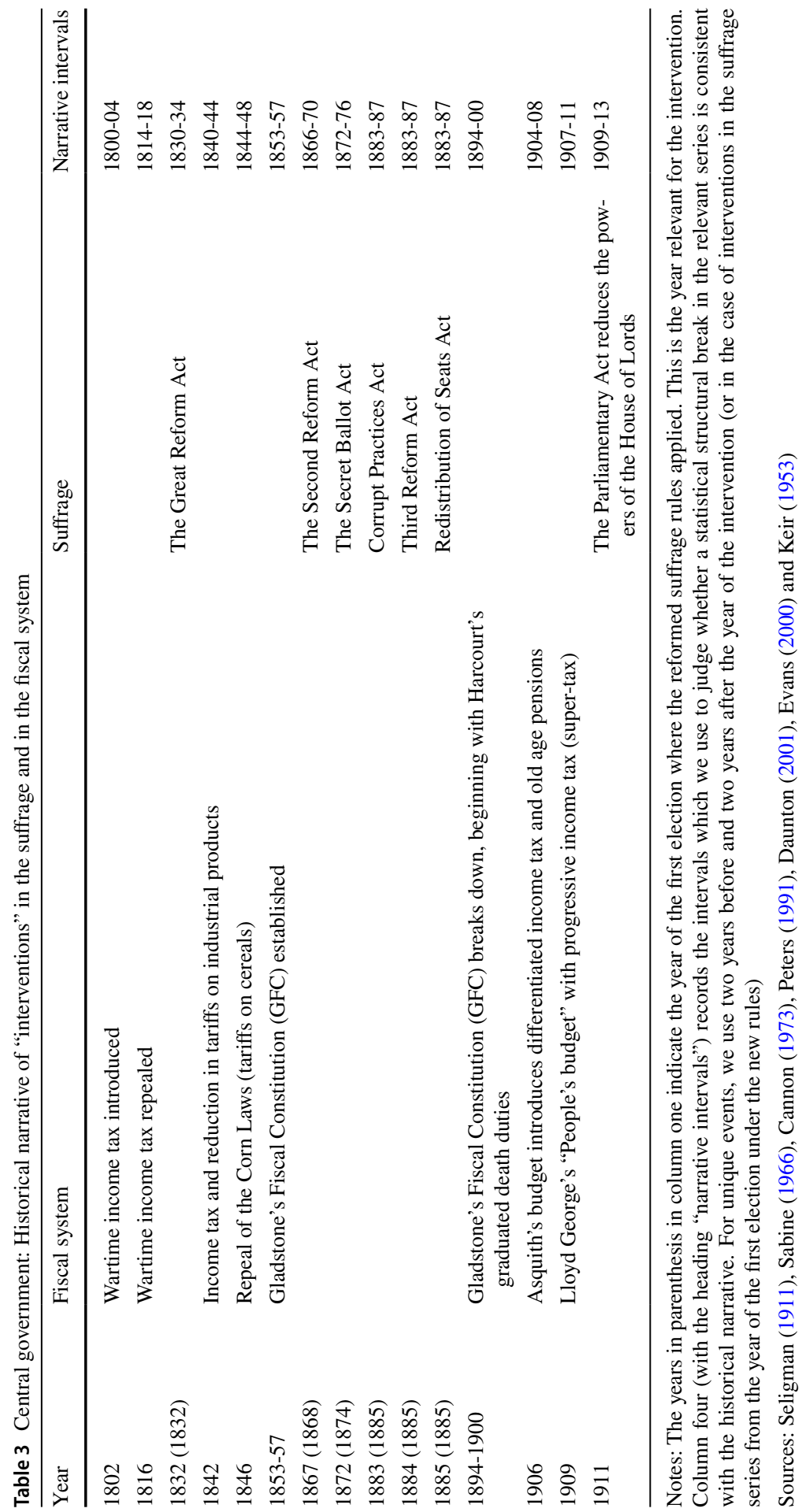


tenants with very small amounts of land. The new rules were first applied in the general election in 1868 and increased the electorate from around eight to 15 percent of the population (Flora et al. 1983). Observers at the time anticipated that the reform would force the two main parties to compete "like Cleon and the Sausage-seller of Aristophanes both bidding for the support of Demos" (Dickinson 1895, p. 64). In the Times (p. 6) on August 16-the day after the reform was voted through-one could read that "some trifling element, ordinarily powerless to influence the result, decides the day" giving voice to the fear shared by many property owners that the extension of the franchise would give political power to voters without any property (Atiyah 1979, p. 589). Turner and Zhan (2012) find that investors on the London stock market shared this fear that the newly enfranchised voters would demand higher taxes and more redistribution and reacted accordingly to news of the reform.

The third step in the franchise extension process was William Gladstone's Representation of the People Act 1884 (the Third Reform Act) and the Redistribution Act 1885. Taken together, the two acts extended the same voting qualifications as existed in the borough constituencies to the counties and distributed seats from the countryside to the urban areas in particular to London (Blewett 1965). In essence, they established the modern one member constituency. The new rules were first applied in the general election in 1886. The size of the electorate expanded from about 16 percent of the population to 29 percent (Flora et al. 1983).

Voting was open till the Ballot Act introduced secret ballot in 1872 (Fitzgerald 1876). The act was aimed at reducing vote buying (Aidt and Jensen 2017). The Corrupt Practices Act of 1883 was a continuation of this and criminalized attempts to bribe voters and standardized the cap on election expenses introduced in 1872 . These two reforms did not have a direct effect on who could vote. However, they might have affected, by creating a more independent electorate, the identity of the de facto median voter and in that way have caused demands for redistribution. Likewise, the Parliamentary Act of 1911, which removed the right of the House of Lords to veto bills related to taxation and public spending (so-called money bills) completely, might have given more effective power to the median voter among the electors for the House of Commons (Keir 1953).

We stop the analysis in 1913, i.e. before the Representation of the People Act 1918. The rationale for this is that this act was introduced at the end of the war. The war and its aftermath is likely, as argued by Scheve and Stasavage (2016), to have affected both the fiscal system (need for war time spending) and the franchise (votes as compensation for fighting). This also excludes the 1928 reform that granted women the right to vote. 5

\subsubsection{The fiscal system for the central government}

We start in 1820 after the Napoleonic Wars. The revenue demands of the Wars were met partly by debt and partly by the first British income tax. After the war

\footnotetext{
5 Women's suffrage is likely to have a different logic unrelated to the redistribution hypothesis (Hicks 2013).
} 
in 1816, the wartime income tax was repealed. As a consequence, the tax base in 1820 was very narrow and relied heavily on indirect taxes (customs and excise duties) with direct taxes, such as land and assessed taxes, contributing less than 15 percent of the total.

Between Victory at Waterloo and World War I, the fiscal system was subject to seven major fiscal interventions which could have induced structural breaks in the level and structure of central government spending and taxation (see Table 3). The first major fiscal intervention was Sir Robert Peel's reintroduction of the income tax in 1842, as a temporary measure to close a budget deficit and to fund the removal of tariffs on industrial goods (Seligman 1911, Chapter XX). The blueprint was the 1806 wartime income tax with a non-differentiated flat rate tax of 2.9 percent (seven pence in the pound) with the exception threshold being about $£ 150$ per year. Babbage (1852) estimates that at most 150,000 of the electors under the 1832 franchise had an income above this threshold. The tax contributed about 10 percent of total revenue in 1844 (Mitchell and Deane 1962, p. 392). It was renewed, first, in 1845 and then again in 1848 and 1853, and for the next 50 years repeated attempts were made to repeal it but without success.

The second major intervention was Sir Robert Peel's repeal of the Corn Laws in 1846 (Aydelotte 1967). The Corn Laws had been introduced in 1815 to protect the agricultural sector though tariffs on imported food and grain ("corn"). Its repeal, which happened despite significant opposition from within Peel's own party (the Tory party), was a victory for supporters of free trade (SchonhardtBailey 2006) and helped to entrench the income tax.

The third major intervention was William Gladstone's first budget as Chancellor of the Exchequer in 1853. It laid the foundation for the "Gladstonian Fiscal Constitution" which was firmly established by 1856-57. The constitution or social contract aimed at achieving fiscal retrenchment and at securing broad agreement on the principles underpinning government budgeting. Daunton (2001, pp 66-68) describes the three pillars of the constitution:

1 Budget unity: All revenue should be unified and treated as a single pool of money which was separate from the purposes for which it was to be spent. This meant a stop to the practice of hypothecation of tax revenues (the pledge of taxes to a specific purpose) and required new accounting practices and the system of double-entry bookkeeping was extended to all government departments in 1857 .

2 No virement of funds and annual votes: All expenditure items were minutely subdivided subject to annual votes in the House of Commons. Surplus funds from one budgetary head could not be moved to another (the principle of no virement) and were allocated to a sinking fund to repay the (war) debt.

3 The Goulburn principle: The tax system as a whole should exhibit a balance between different types of taxes (direct and indirect) so that the various social classes all contributed a fair share to the total. This should be achieved by compensatory taxes rather than graduation of any particular tax. 
The Gladstonian Fiscal Constitution became fiscal orthodoxy for over four decades. Its limits, however, started to show in the mid 1890 s and by 1900 , the consensus behind the Constitution had all but broken down. We have identified four potential interventions in the fiscal system between 1894 and 1909 that contributed to the demise of Gladstonian public finance and could have caused a structural break in the fiscal system. The first major challenge came in 1894, when the Chancellor of the Exchequer, William Harcourt, achieved parliamentary approval for graduated taxation of estates at death. This prepared the way for the later reforms of the income tax by the Liberal politicians Herbert Henry Asquith in 1906 and Lloyd George in 1909. The next intervention happened as a consequence of the Boer war in 1899-1902. To fund the war, the income tax had to be raised to an unprecedented 6 percent and direct taxes for the first time raised more revenue than indirect taxes (Sabine (1966), Chapter 6). The third intervention came in 1906 when a Select Committee in the House of Commons concluded that graduation and differentiation of the income tax were both feasible. The report was quickly turned into legislation by the Liberal Chancellor Herbert Henry Asquith. He introduced in his 1906 budget differentiated taxes on earned and unearned income for the first time and also introduced the first old-age pension-the start of the welfare state. Lloyd George's People's Budget from 1909 introduced the graduated super-tax into the income tax schedule, and this dealt the final blow to the Gladstonian Fiscal Constitution.

\subsection{Historical narrative: municipal government in England and Wales 1867 to 1912}

Local government in England and Wales consisted of a complex variety of local authorities with different powers to tax and spend, with different governance rules and covering different geographical units (see, for example, Smellie 1946). The Municipal Boroughs and the Urban Sanitary Authorities were the most important of these local government authorities in provincial towns and the only authorities for which systematic quantitative data on the franchise can be found. Public finance data are available from 1867 to 1912, and we focus the historical narrative on this period.

\subsubsection{The municipal franchise}

The Municipal Corporation Act 1835 established the legal framework for the yearly elections to the councils of the Municipal Boroughs. The municipal franchise was granted to male taxpayers who had paid the local property tax (called the rate), who had lived in the borough for two-and-a-half years and who had registered to vote. In contrast to the 1832 Parliamentary franchise discussed above, which imposed a property value threshold on the right to vote, the franchise for the local elections applied no such threshold and upheld the principle of "one taxpayer one vote". However, as discussed by Keith-Lucas (1952, Chapter 3) this did not, in practice, give voting rights to "poor" householders. Firstly, it was common that properties of low 
Table 4 Local government: Historical narrative of "interventions" in the municipal franchise and in the Municipal Boroughs' fiscal system, 1867-1912

\begin{tabular}{llll}
\hline Year & Fiscal system & Municipal suffrage & Narrative intervals \\
\hline 1869 & & Municipal Franchise Act & $1868-72$ \\
1875 & The Public Health Act & The Parliamentary and Munici- & $1877-81$ \\
1878 & & pal Registration Act \\
& & Municipal Corporation Act & $1881-85$ \\
1882 & & County electors act & $1887-91$ \\
1888 & & & $1887-91$ \\
$1888(1889)$ & The Local Government Act & Local Government Act & $1893-97$ \\
1894 & & & $1900-04$ \\
1902 & The Education (Balfour) Act & &
\end{tabular}

Notes: Column four (with the heading "narrative intervals") records the intervals which we use to judge whether a statistical structural break in the relevant series is consistent with the historical narrative. We use two year before and two years after the intervention to define these intervals. For interventions in the suffrage, we take into account that one one-third of the local government councils were elected each year and centre the interval on the second election under the new rules (in the year after the adoption of the reform). For the interventions in the fiscal series, we centre the interval on the fiscal year of the intervention. The years in parenthesis in column one indicate the year in which the legislation took effect if different from the year of adoption

Sources: Vine (1878), Vine (1882), Keith-Lucas (1952), Keith-Lucas (1977), Daunton (2001), Davis (2000), Millward (2000), Doyle (2000), Smellie (1946), Redlich and Hirst (1958) and Eaglesham (1967)

value were exempt from paying the rates, which then automatically disenfranchised the occupiers. Secondly, the long residency requirement excluded many workers in the expanding industrial cities because they moved around a lot. Thirdly, many tenants were indirect ratepayers in the sense that their landlord paid the rate on the property they occupied and it was initially unclear whether they qualified for the vote (Daunton 2001, Chapter 9). The suffrage granted in 1835 gave the right to vote to about 6 percent of the population in the Municipal Boroughs.

The suffrage was gradually extended over the next 70 years through national legislation that reduced the residency requirement and clarified the rights of indirect ratepayers and tenants living in shared accommodation (lodgers). Table 4 lists five key interventions in the municipal franchise in the years after 1867. The Municipal Franchise Act of 1869 reduced the residency requirement from two-and-a-half years to one year, added "other buildings" to the list of qualifying properties and gave unmarried women who satisfied the other franchise requirements the right to vote (Vine 1878, p. 45-46). The Act had a big effect on the electorate: it increased from 9 to about 14 percent of the population. The Parliamentary and Municipal Registration Act of 1878 and the Municipal Corporation Act of 1882 settled the ambiguity related to indirect taxpayers and established that they did qualify to the vote in local elections (Keith-Lucas 1952, Chapter 3). The two acts increased the share of voters from about 14 percent to 17 percent of the municipal population. Two other bills, although not aimed specifically at the Municipal Boroughs had, nonetheless, implications for the municipal franchise. The County Electors Act of 1888, which 
introduced elected councils in the counties, gave those who had obtained the right to vote in parliamentary elections in 1885 the right to vote also in local elections and the Local Government Act of 1894 added lodgers to the electorate. The two reforms had only a minor effect on the size of the municipal electorate.

\subsubsection{The municipal fiscal system}

The fiscal responsibilities of the Municipal Boroughs were based on two fundamental principles (Waller 1983). Firstly, local expenditures were funded locally, either out of estate income or through the local property tax. Grant-in-aid from the central government was minimal and debt could only be issued for specific investment projects. Secondly, within the statutory duties laid down by law, the Municipal Boroughs had much flexibility to decide the scale of their activities and the quality and quantity of the services they wished to supply. The Municipal Boroughs were responsible for administration of justice, the police and for public property. Importantly, where a borough acted as urban sanitary authority, it also was responsible for investments in clean water, sewage systems, garbage removal, maintenance and improvement of thoroughfares and paving of streets (Vine 1878, p. 15).

Table 4 lists three potential interventions in the local fiscal system. ${ }^{6}$ The first major intervention was the Public Health Act 1875. The act gave the boroughs that were or became urban sanitary authorities new fiscal powers, including the power to purchase, repair or create sewers, to control water supply, to regulate cellars and lodging houses and to establish bye-laws for controlling new streets and buildings.

The second major intervention was the Local Government Act 1888, which came into force on April 1889. The act established county boroughs in 59 of the largest Municipal Boroughs (with a population of more than 50.000 in 1881). This gave these boroughs new tax and borrowing powers, new responsibilities for county assets, repair of county roads and bridges, and the responsibility for the establishment and maintenance of reformatory and industrial schools (Davis 2000, p. 269-71).

The third intervention was the Education (Balfour) Act 1902 (see Eaglesham 1967). Prior to the Balfour Act, primary education was outside the remit of the boroughs. The act gave the county boroughs significant new fiscal responsibilities and powers in relation to elementary and secondary schools in their jurisdiction.

\section{The data}

We have collected historical data quantifying the gradual extension of the suffrage (e) and the evolution of the fiscal system $(f)$ for the period 1820 to 1913 (the central government) and 1867 to 1912 (the municipalities). We measure the extension of the

\footnotetext{
6 The Public Health Act 1872 did not have a direct effect on the public finances. Likewise, the Local Government Act 1894, which as noted in Sect. 3.2.1 affected the suffrage, did not directly change the fiscal powers and responsibilities of the Municipal Boroughs but renamed the urban sanitary districts as urban districts.
} 


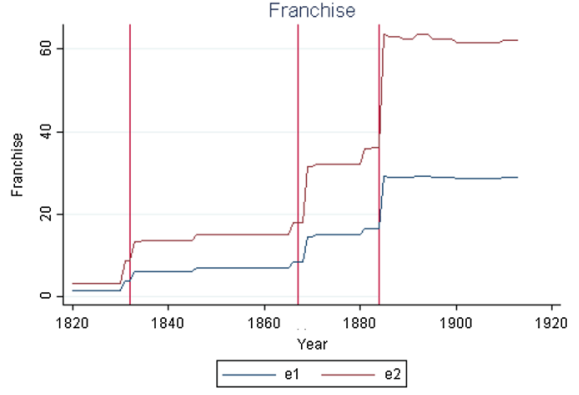

(a) Franchise $\left(e_{1}\right.$ and $\left.e_{2}\right)$

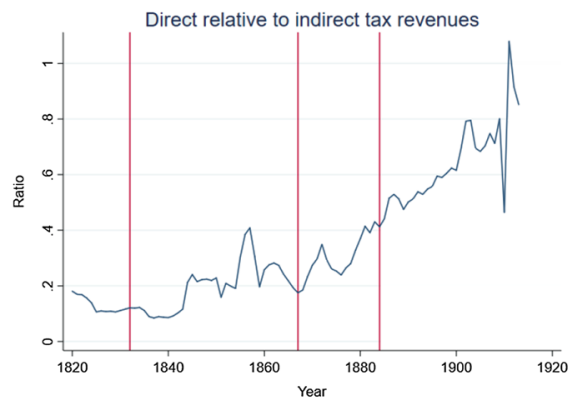

(c) Direct/indirect tax $\left(\frac{T^{d}}{T^{i n}}\right)$

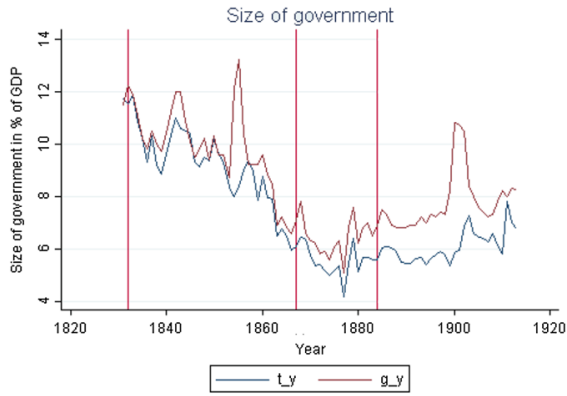

(b) Government $\operatorname{Size}\left(\frac{G}{Y}\right.$ and $\left.\frac{T}{Y}\right)$

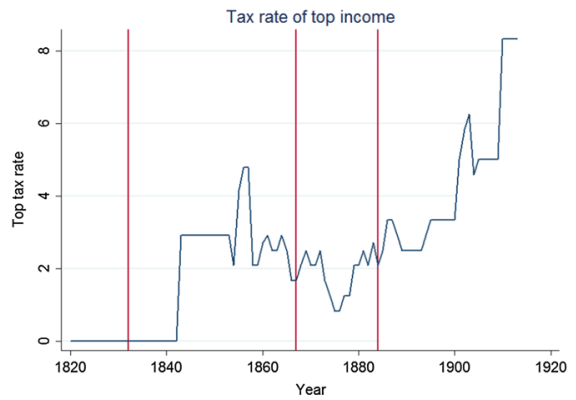

(d) Top Income Tax Rate (Top)

Fig. 1 Evolution of the franchise and the fiscal variables for central government in the UK, 1820 to 1913. Notes: Panel (a) shows the two measures of the franchise for elections to the House of Commons. $e_{1}$ is the proportion of the adult population with the right to vote in parliamentary elections. $e_{2}$ is the proportion of the adult male population with the right to vote in parliamentary elections. Panel (b) shows the two measures of the size of government. $\frac{T}{Y}$ is total tax revenue out of GDP and $\frac{G}{Y}$ is total spending out of GDP. Panel (c) shows the ratio of direct to indirect tax revenue $\frac{T^{d}}{T^{i n}}$. Panel (d) shows the top marginal income tax rate (top). The red vertical reference lines indicate the years with suffrage reforms (1832, 1867 and 1884)

franchise that governed elections to the House of Commons in two ways (Flora et al. 1983; Caramani 2000). The first measure is the proportion of the adult population with the right to vote in parliamentary elections $\left(e_{1}\right)$; the second measure is the proportion of the adult male population with the right to vote in parliamentary elections $\left(e_{2}\right)$ and thus excludes women from the denominator. Figure 1a plots the two suffrage series. The vertical red lines are the suffrage reforms of 1832, 1867 and 1884, respectively. We notice the step pattern of these series which captures the process of including men with progressively lower income in the electorate and the corresponding fall in the income of the median voter. We do, however, observe some variation between 


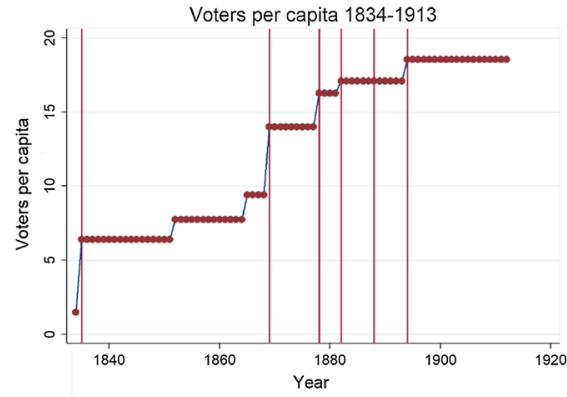

(a) Franchise $e_{1}^{L}$

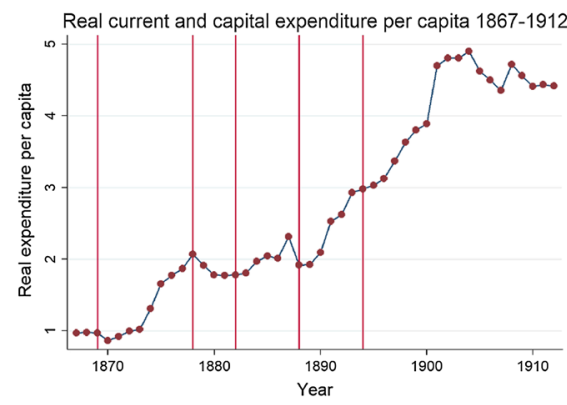

(c) Local government size $\frac{G}{N}$

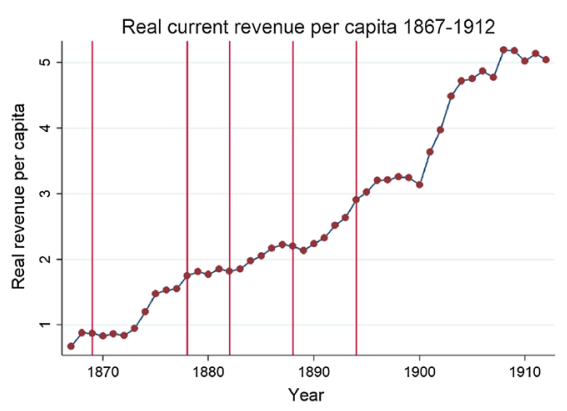

(b) Local government size $\frac{T}{N}$

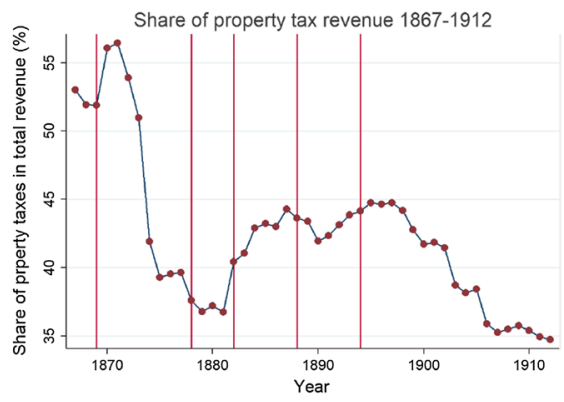

(d) Tax composition $\frac{T A X}{T}$

Fig. 2 Evolution of the franchise and the fiscal variables in the Municipal Boroughs, 1867 to 1912. Notes: Panel (a) shows the evolution of the number of voters per capita registered to vote in local elections to the Municipal Borough councils in England and Wales $\left(e_{1}^{L}\right)$. Panel (b) and (c) show the evolution of total revenue including income from loans $\left(\frac{T}{N}\right)$ and total expenditure including capital spending $\left(\frac{G}{N}\right)$, respectively, expressed in real 1870 prices and per capita. Panel (d) shows the share of income from the property tax in percentage of total revenue $\left(\frac{\mathrm{TAX}}{T}\right)$. The data refer to the Municipal Boroughs in England and Wales which acted as Urban Sanitary Authorities. The red vertical reference lines indicate the years with suffrage reforms as identified in Table 4

the reform years. This is due to changes in registration (voters had to register) and to variation in demographic conditions ${ }^{7}$ and to improving economic conditions. ${ }^{8}$

We measure the extension of the franchise for elections to the Municipal Boroughs in England and Wales as the number of voters registered to vote for municipal elections relative to the size of the municipal population $\left(e_{1}^{L}\right){ }^{9}$ While elections took place yearly, only eight cross sections of suffrage data are preserved in the British Parliamentary Papers and Vine (1878). Based on these cross sections, we construct the time series shown in Fig. 2a. ${ }^{10}$ The vertical lines indicate the years $(1835,1869$,

\footnotetext{
${ }^{7}$ For example, voters who had "old" rights to vote prior to 1832 and who did not quality under the new post-1832 rules kept their right to vote for life, and the electorate would, therefore, contract as these voters died.

${ }^{8}$ For example, the franchise after 1832 had a property value requirement fixed nominally and so growth in property values could enfranchise new voters and expand the franchise that way.

${ }^{9}$ It is not possible to obtain age- and gender-specific demographic data at the correct spatial units to calculate municipal voters per adult male and we also observe that a significant number of property-owning women had the right to vote in local elections.

${ }^{10}$ See Supplementary Appendix A1 for details on data construction and primary sources.
} 
$1878,1882,1888$ and 1894) in which the suffrage for elections to the Municipal Boroughs were extended.

We measure three aspects of the fiscal system: scale, revenue composition and tax rates. We quantify the scale of the central government's fiscal activities by total central government tax revenue relative to GDP $\left(\frac{T}{Y}\right)$ and total central government spending relative to GDP $\left(\frac{G}{Y}\right) .{ }^{11}$ We measure the composition of tax revenues by the ratio of direct to indirect tax revenues $\left(\frac{T^{d}}{T^{\text {in }}}\right)$. Direct taxes include property taxes and taxes on land and various assessed taxes, and from 1842 income taxes and later on corporation taxes. Indirect taxes include commodity taxes (excise duties) and taxes on international trade. Direct taxes are, typically, better geared towards redistribution than indirect taxes and thus we associate an increase in $\frac{T^{d}}{T^{i n}}$ with more redistribution. ${ }^{12}$ We measure the rate structure by the top marginal income tax rates. ${ }^{13}$ These capture the degree of progression in the income tax system. ${ }^{14}$

Figure $1 \mathrm{~b}$ to $\mathrm{d}$ shows the central government's fiscal series. The vertical red lines indicate the years of the three (national) suffrage reforms (1832, 1867 and 1884, respectively). Panel (b) shows the scale, measured either by total tax revenue out of GDP $\left(\frac{T}{Y}\right)$ or total spending out of GDP $\left(\frac{G}{Y}\right)$. We observe a long period of retrenchment between 1820 and 1875 where government spending and taxation fail to keep up with the expansion of the economy, and taxation and spending fall from about 10 percent of GDP to about 6 percent. The downwards trend breaks in the mid1870 s and by 1913 , the expenditures and taxes stand at about 8 percent of GDP. The Crimean War (1853-56) and Boer War (1899-1902) are clearly visible spikes in spending (and in the income tax rate in Panel (d)). Panel (c) shows the evaluation of the composition of tax revenues $\frac{T^{d}}{T^{i n}}$. At the beginning of the period, the indirect taxes contribute 8 times as much as the direct taxes. The 1842 income tax reduces this to a factor of about 4 and the importance of indirect taxes continues to fall after that. By 1913, the ratio is close to one. Panel (d) shows the evolution of the top marginal income tax rate. The top income tax rate varies between a little under 1 percent to a maximum of 9 percent in 1909. We observe a gradual fall in the top rate between 1842 and 1879, after which it slowly increases by 8 percentage points. As discussed above, graduation in the income tax was not introduced till 1909, so for most of the period the marginal tax rate is the standard tax rate.

For local government, the Local Taxation Returns (contained in the British Parliamentary Papers) record for each Municipal Borough and Urban Sanitary

\footnotetext{
11 The series are constructed from data reported by Flora et al. (1983) and Maddison (2003).

12 Flora et al. (1983) report information on revenue sources which we supplement with information from Mitchell and Deane (1962, Chapter XIV).

13 The source of these data is Scheve and Stasavage (2016).

14 We have experimented with many other fiscal variables, including total real spending and taxation, a finer decomposition of taxes by source, public debt and bond rates, and the composition of spending. The three aspects we focus on in the reported analysis, we believe, are a good representation of the evolution of the fiscal system's redistributive characteristics between 1820 and 1913 at the level of central government.
} 
Authority detailed expenditure and revenue accounts. We have aggregated these and constructed time series representing the local government fiscal system. ${ }^{15}$ We measure the scale of fiscal activity by real revenue per capita $\left(\frac{T}{N}\right)$ and real expenditure per capita $\left(\frac{G}{N}\right)$. We normalize with the total municipal population to account for population growth and also for the fact that the number of Municipal Boroughs expanded over time. We measure the revenue composition as property taxes as a share of total revenue $\left(\frac{\mathrm{TAX}}{T}\right)$. The two main alternative sources of revenues to property taxes were estate income and income from municipal operated public services (e.g. water or gas works). We interpret a higher share of property taxes as a more progressive local tax system. It is not possible to obtain consistent data on the property tax rates.

Figure $2 \mathrm{~b}$ and $\mathrm{c}$ graph total real revenue and total expenditure per capita for the Municipal Boroughs between 1867 and 1912 while panel (d) graphs the share of property tax revenue relative to total revenue. The vertical red lines indicate years of (local) suffrage reform (see Table 4). We observe a gradual increase in both revenue and expenditure over time, with an acceleration in the 1890s and a flatting out before World War I. The share of property tax revenues fell dramatically in the first half of the 1870 s reflecting that many boroughs got involved in the running of local utilities (gas and water) which were major revenue generators (Millward 2000).

\section{The statistical analysis}

The statistical analysis proceeds in three steps: first, pre-filtering; second, structural breaks analysis; third, an application of the algorithm introduced in Sect. 2 that combines the historical narrative analysis with the structural breaks analysis to establish causality. All the statistical tests are conducted on the time series introduced in the previous section covering the period 1820 to 1913 (central government) or 1867 to 1912 (local government).

A prerequisite for applying the Hoover approach is that reasons for breaks in the marginal and conditional distributions of measures of the franchise $e$ and the fiscal system $f$ other than those directly related to interventions in the two processes themselves have been removed prior to testing for structural breaks. Failure to do so appropriately casts doubt on whether the statistical pattern of structural breaks are informative of the true casual relationship between $e$ and $f$, as those structural breaks could be caused by a common confounding intervention. The method, then, requires that after pre-filtering there are no remaining omitted factors that cause breaks in $e$ or $f$. This is a different and weaker assumption than the conditional independence assumption required for causal interpretation of a standard linear regression.

For the analysis of central government data, we use movements in real GDP per capita (Maddison 2003) and a dummy variable that codes for years at which the UK was at war (including across the British Empire) to filter $e$ and $f$ for the effect of war and for shocks to the economy structure. We do so by regressing the six time series on a dummy variable for years with war and on real GDP per

15 It is not a trivial matter to construct these series. Supplementary Appendix A1 explains in detail now we dealt with a range of data consistency and aggregation issues. 
capita with data covering the period 1820-1913. The residuals from these regressions isolate the evolution of the suffrage and the fiscal system net of shocks caused by war and economic change. Any structural breaks that are left are then not caused by these two potential confounders. For municipal government, wars are not likely to be a confounding factor, but shocks to the economy structure are and we filter $e$ and $f$ for the municipalities with movements in real GDP per capita. To avoid cumbersome notation and terminology, we refer henceforth to these filtered data series (the residuals) by the notation and name of the underlying series.

We begin the structural breaks analysis by establishing the order of integration of the (filtered) data series. Based on that, we formulate appropriate autoregressive-distributed lag (ARDL) models for the conditional distributions where the dependent variable is explained by lagged values of itself and by the current value and successive lags of the conditioning variables. The ARDL models are reduced to autoregressive (AR) models for the marginal distributions where the dependent variable is regressed on a number of its own lags. The optimal lag orders are determined by minimizing Akaike's information criterion (AIC) and by making sure the residuals of the models are serially independent and dynamically stable. Adding lagged terms also control for gradual changes in the franchise and the fiscal series that may happen in reality but do not help establish causality in the Hoover approach. We use the five varieties of the Bai-Perron test to locate statistical breaks in the ARDL (AR) representations of the marginal and conditional distributions. We test the structural breaks on both the coefficients of level or lagged terms as well as the constant. Supplementary Appendix A2 provides details on this.

\section{The results}

The results of the structural breaks are reported in Supplementary Appendix A2. To implement test A and B (Table 2) and establish the causal relationship between the measures of the franchise $e$ and the fiscal system $f$ from the structural breaks tests, we follow two rules. The first rule determines when interventions identified in the historical analysis match up with the structural breaks identified by the statistical analysis. Arguably it takes time for a change in the suffrage rules to cause a change in the fiscal structure and vice versa and there could be anticipation effects. For each series, we, therefore, define a "narrative interval" of plus/minus 2 years around the year identified in the historical narrative analysis as the intervention year. These are listed in column (4) of Table 3 and Table 4. Specifically, for the suffrage series for the House of Commons, this allows for a lag of two years after the first election in which the new suffrage rules were applied, i.e. roughly corresponding to one parliament. At the local level, where elections took place yearly, it allows for the effect on the fiscal system to happen up to two years after two-thirds of the councillors had been elected under the new rules. We investigate longer lags in sect. 6.1.3. The second rule determines when we accept that a statistical break falling within a given 
Table 5 Direction of Causality Based on the Patterns of Structural Break Points and the historical narrative

\begin{tabular}{|c|c|c|c|c|c|}
\hline \multirow[t]{2}{*}{ Franchise } & \multirow[t]{2}{*}{ Fiscal } & \multicolumn{4}{|l|}{ Years with } \\
\hline & & $e \perp f$ & $e \leftrightarrow f$ & $e \rightarrow f$ & $f \rightarrow e$ \\
\hline \multicolumn{6}{|c|}{ Panel A: Test A } \\
\hline$e_{1}$ & $T^{d} / T^{\text {in }}$ & $(1866-70)^{a}$ & & & $1883-87$ \\
\hline$e_{2}$ & $T^{d} / T^{i n}$ & & & & \\
\hline$e_{1}$ & $G / Y$ & $(1866-70)^{a}$ & & $1883-87^{c}$ & \\
\hline$e_{2}$ & $G / Y$ & & & & \\
\hline$e_{1}$ & $T / Y$ & & & & $1883-87,(1866-70)^{a}$ \\
\hline$e_{2}$ & $T / Y$ & & & & \\
\hline$e_{1}$ & Top & & & & $1883-87,(1866-70)^{a}$ \\
\hline$e_{2}$ & Top & & & & \\
\hline \multicolumn{6}{|c|}{ Panel B: Test B } \\
\hline$e_{1}$ & $T^{d} / T^{i n}$ & $1807-11$ & & & \\
\hline$e_{2}$ & $T^{d} / T^{\text {in }}$ & & & & \\
\hline$e_{1}$ & $G / Y$ & & & & \\
\hline$e_{2}$ & $G / Y$ & & & & \\
\hline$e_{1}$ & $T / Y$ & $1853-57$ & & & \\
\hline$e_{2}$ & $T / Y$ & $1844-48,1994-00$ & & $1853-57$ & \\
\hline$e_{1}$ & Top & $1894-00$ & & $(1894-00)^{b}$ & \\
\hline$e_{2}$ & Top & $1894-00$ & & & \\
\hline
\end{tabular}

Notes: All data are filtered with War Dummies and GDP per capita. Based on Test A and B from Table 2, the table reports the years in which it is possible to draw a causal conclusion based on the structural break test results reported in Supplementary Appendix Table A4 and A5 and the historical narrative analysis summarized in Table 3. Test A requires that there is an intervention in the franchise series according to the historical narrative in the years with statistical breaks. Test B requires that there is an intervention in the fiscal series according to the historical narrative in the years with statistical breaks. $\perp$ means independent, $\leftrightarrow$ means causality in both directions, and $\rightarrow$ means direction of causality. For test A, the years 1883-87 are the 3rd Reform Act. For test B, the years 1844-48 are the repeal of the corn laws, 1853-57 are the beginning of the Gladstone's fiscal constitution, 1894-1900 is the end of the Gladstone's fiscal constitution, and 1904-08 is Asquith's budget. We allow for plus/minus two years around the event identified in the narrative analysis. a. One break only in $D\left(e_{1}\right)$ in this period. b. One break only in $D\left(e_{1} \mid\right.$ Top $)$ in this period. c. The result is not robust to adding the consol rate on government bonds to the set of variables used to pre-filter the series

interval has, in fact, occurred. We apply two alternative criteria: the strict criterion requires that at least two of the five Bai-Perron tests find a break; the weak test requires that one does. We report results with both criteria below and indicate with brackets which are based on the weak criterion. 


\subsection{Central government}

\subsubsection{Main results for central government}

Based on the test results and the historical narrative, we apply the algorithm outlined in Sect. 2 to determine the nature of the causal relationship between the franchise for the House of Commons and the fiscal system of the central government (if there is one). This requires applying test A and B systematically to the pattern of breaks we find and checking for consistency with the historical narrative. Supplementary Appendix A3 reports the details of how this is done. Convincing evidence for a particular causal pattern must come from both tests: Test A tells us which causal relationship is consistent with historically verified interventions in the franchise series and test B tells us which causal relationship is consistent with the historically verified interventions in the fiscal system. Table 5 summarizes the results, with panel A showing the years when test $\mathrm{A}$ is conclusive and panel $\mathrm{B}$ showing the years when test $\mathrm{B}$ is conclusive.

We find one case in which test A, test B and the historical narrative are consistent with the Redistribution Hypothesis. First, the break pattern around the 3rd reform act in 1883-87-statistical breaks in all series except $D\left(e_{1} \mid \frac{G}{Y}\right)$-implies that $e_{1}$ causes $\frac{G}{Y}$ (test A). Second, the break pattern around the beginning of the Gladstonian Fiscal Constitution-statistical breaks in all series related to $\frac{T}{Y}$ except $D\left(e_{2}\right)$ -implies that $e_{2}$ causes $\frac{T}{Y}$. However, the evidence should be judged against the fact that for the three other fiscal series than $\frac{G}{Y}$, test A suggests reverse causality from the fiscal system $f$ to the franchise $e$ around the 3 rd reform act (1883-87) and the evidence from the 2 nd reform act (1866-70) either points to independence or reverse causality from the fiscal system to the suffrage. The indications of reverse causality from test A are, however, not confirmed with any evidence from test B that fiscal innovation causes suffrage reform, and so are not compelling.

The fact that we find that the franchise causes government expenditure size to grow, but not tax size raises the question as to what is in the evolution of $\frac{G}{Y}$ that is not in $\frac{T}{Y}$. The obvious answer is the deficit, which, in turn, suggests that shocks to the interest rate paid on debt may be confounding the relationship between the franchise and government size. This suspicion is bolstered by simple (autoregressive) regressions of $\frac{G}{Y}$ and of $\frac{T}{Y}$ on GDP per capita, the war dummy and the consol rate for government bonds, in which the consol rate is statistically significant in the former regression but not in the latter. If we add the consol rate to the set of variables used to filter the franchise and fiscal series, the result in Table 5 that $e_{1}$ causes $\frac{G}{Y}$ under test A disappears.

In summary, the causal evidence that the Third Reform Act 1884 triggered an increase in government spending relative to GDP has a question mark hanging over it because we do not find a similar effect for government revenue and because the pattern of statistical breaks required to pass test $\mathrm{A}$ is not robust to filtering with the consol rate. We must, therefore, conclude that we do not find compelling evidence that the franchise $e$ causes the fiscal system $f$. 
Table 6 Local Government: Direction of Causality Based on the Patterns of Structural Break Points

\begin{tabular}{llllll}
\hline Franchise & Fiscal & \multicolumn{2}{l}{ Years with } & & \\
\cline { 3 - 5 } & & $e \perp f$ & $e \leftrightarrow f$ & $e \rightarrow f$ & \\
\hline Test $A$ & & & & \\
$e_{1}^{L}$ & $\mathrm{TAX} / T$ & $1868-72$ & & \\
$e_{1}^{L}$ & $G / N$ & & & \\
$e_{1}^{L}$ & $T / N$ & $1868-72$ & & \\
Test $B$ & & & & \\
$e_{1}^{L}$ & $\mathrm{TAX} / T$ & $1873-77,1900-72)^{a}$ & \\
$e_{1}^{L}$ & $G / N$ & $1887-91$ & & \\
$e_{1}^{L}$ & $T / N$ & $(1887-91)^{b}$ & & \\
\hline
\end{tabular}

Notes: All series are filered with real GDP per capita. Based on Test A and B from Table 2, the table reports the years in which it is possible to draw a causal conclusion based on the structural break test result reported in Supplementary Appendix Table A4 and A5 and the historical narrative analysis summarized in Table 3. Test A requires that there is an intervention in the franchise series according to the historical narrative in the years with statistical breaks. Test B requires that there is an intervention in the fiscal series according to the historical narrative in the years with statistical breaks. $\perp$ means independent, $\leftrightarrow$ means causality in both directions, and $\rightarrow$ means direction of causality. For test A, the years 1868-72 are the Municipal Franchise Act 1869. For test B, the years 1873-77 are the Public Health Act 1875, 1900-04 are the Education (Balfour) Act, and 1887-91 are the Local Government Act of 1888. We allow for plus/minus two years around the event identified in the narrative analysis. a. Only one test finds a break in $D\left(\frac{\text { TAX }}{T}\right)$. If we use the stricter criterion that we need two tests to confirm a break, we conclude that $\frac{\text { TAX }}{T} \perp e_{1}^{L}$. b. Only one test finds a break in $D\left(\frac{T}{N}\right)$ in this period

\subsubsection{The choice of pre-filtering variables}

Previously, we argued that it is important to filter for the effect of war and shocks to the economic structure and possibly also in some cases for the effect of the consol rate. This may, however, lead to "over-smoothing" of the series, i.e. the possibility that genuine breaks in a series are masked by over-fitting them. Tables A7 to A9 in Supplementary Appendix A4 report the results from an analysis of data that are only filtered for war. With this more parsimonious pre-filtering, we do not find that $e_{1}$ causes $\frac{G}{Y}$ in $1883-87$. The fact that we can find a break in $\frac{G}{Y}$ when we filter with both war and GDP per capita but not when we only filter for war is obviously not a result of over-fitting, but may be due to the magnitude of the "break" in 1884 being small relative to the one in 1853-57. This makes it hard for the global Bai-Perron tests to detect any break in government size in the mid 1880s without first filtering with GDP per capita, which mitigates the magnitude of the breaks in 1853-57 and makes 1883-87 stand out.

\subsubsection{Allowing for longer time lags}

It is valid to question how long it might take for suffrage reform to affect fiscal policy. We have allowed for roughly one parliament so far. In Table A10 in 
Supplementary Appendix A4, we report how the results are affected if we allow the lag to be around two parliaments (second election under the new rules plus 2 years). This does not make any substantive difference for the results for the Third Reform Act 1884 and the Redistribution Act 1885. However, with longer lags we find evidence that the franchise caused the fiscal system for $\frac{G}{Y}$, but only with one of the Bai-Perron tests, around the Second Reform Act of 1867. We observe that the support for the Redistribution Hypothesis is stronger when we allow for a longer lag between suffrage reform and structural breaks in the fiscal system, but not to an extent that substantively changes our main conclusion.

\subsection{Local government}

To determine the causal relationship between the franchise $e$ and the fiscal system $f$ for the Municipal Boroughs from these tests and the historical narrative, we, again, apply the Hoover algorithm. Table 6 reports the results. Based on test A, we find one indication that the Municipal Franchise Act in 1869 may have caused the subsequent drop in $\frac{\mathrm{TAX}}{T}$. The required break in the marginal distribution for $\frac{\mathrm{TAX}}{T}$ is, however, only detected by one of the Bai-Perron tests, and if we use the stricter criterion that a break must be detected by two of the five tests, test $\mathrm{A}$ implies that the two series are independent. Test B, however, does not detect any instances consistent with the franchise causing the fiscal system and the suffrage and fiscal structure appear to be independent. This casts doubt on the reliability of the finding from test A.

In conclusion, we do not find compelling evidence that the franchise causes the fiscal system at the local level. If anything, the patterns of structural breaks suggest that it does $(e \rightarrow f)$ in the years around the Municipal Franchise Act 1869, but at a time when property taxes as a share of total revenue fell dramatically, possibly reflecting the fact that many of the newly enfranchised taxpayers wanted fiscal economizing and retrenchment, not fiscal expansion and redistribution (Szreter 1988; Daunton 2001; Aidt et al. 2010).

\section{Conclusion}

Our analysis, both at the central and at the local government level, does not find compelling evidence in support of the Redistribution Hypothesis despite the substantial and sequentially implemented reforms of the franchise governing elections at both levels of government. We find one break - the 3rd Reform Act 1884-where the historical narrative and the pattern of structural breaks are consistent with a causal effect from the suffrage to government spending relative to GDP. However, we cannot find a similar effect on the revenue side and the break pattern needed to support a causal interpretation disappears if we filter the series for the consol rate or if we do not filter for GDP per capita. This casts doubt on this finding. We also find instances in which interventions to the fiscal system-in particular the fiscal rules laid down by William Gladstone in the 1850s and dismantled in the 1890s—and 
the pattern of structural breaks are consistent with the Redistribution Hypothesis, in the sense that these structural shifts in fiscal policy did not affect the franchise process, which was evidently independent of them. For local government, we also find one instance-the Municipal Franchise Act 1869-where the historical narrative of the suffrage and the statistical break patterns are consistent with the Redistribution Hypothesis, but this cannot be backed up with similar evidence from the narrative of the evolution of the fiscal system, which makes that evidence uncompelling. Overall, then, we do not find compelling causal evidence favoring the Redistribution Hypothesis.

To conclude, we speculate on the reasons why we are not, despite its logical appeal, able to find unambiguous causal evidence of the Redistribution Hypothesis. There are at least five possibilities. First, there is the problem of measuring redistribution. We do not have direct measures of redistributive intent by the governments of the day. This would be the best outcome indicator. Our indicators try to proxy for redistribution but do not capture finer adjustments to poor law expenditures or unemployment benefit. Moreover, we focus on redistribution through the fiscal system. This leaves open the possibility that redistribution could have taken place indirectly through non-fiscal interventions, for example, in the labor market (e.g. allowing trade unions or introducing factory regulation) or in international trade (e.g. a liberalization that increases the factor rewards of certain factors of production).

Second, we study the relationship between voting rights and the fiscal structure at a given level of government and not the interaction between different levels of government. This ignores the possibility that the national government, after a (national) franchise extension, could introduce new legislation that forces or enables local government to change its fiscal structure but without any direct effect on the public finances of central government. For example, when the British House of Commons enacted the Elementary Education Act in 1870 - three years after the Second Reform Act-it set up local education boards to provide state-run education for children aged 5 to 13 . These boards were partly funded through local property taxes and thus all the extra public spending on education did not show up in the national budget. Insofar as the Act was a consequence of the suffrage reform in 1867 and the new state-run schools benefited the newly enfranchised voters, this would be consistent with the Redistribution Hypothesis, but not be detected by our tests. Likewise, when the government elected in 1832 after the Great Reform Act reformed the Old Poor Laws - the locally funded and administered support system for the poorthey gave local government new responsibilities without leaving a trace in central government public finances.

Third, there is the problem of complexity. There are many economic, social and political changes occurring at the same time in the history we (and others) explore that make the task of controlling for unrelated events difficult. In the course of our investigations, we have isolated one set of interventions - the Gladstone reforms of the budget process and their demise - and have shown them to be clearly independent of the process underlying the franchise. There may be other shocks that we have not been able to deal with as neatly.

Fourth, the Hypothesis may be "incomplete". For example, it may be that the context in which franchise extension occurs is almost always one in which suffrage 
and redistribution are determined more or less simultaneously as part of broader social developments. In other words, the franchise, fiscal structure and redistribution may be joint indicators of broader or deeper social developments, the exogenous shocks to, or drivers of which are somewhere outside of what we think of when we formulate the Redistribution Hypothesis.

Finally, at its core the Redistribution Hypothesis is a hypothesis about the demand for redistribution coming from the newly enfranchised voters. This assumes a passive supply side response: the elected representatives and parties they represent simply cater to these demands. In practice, this is too simplistic. It takes time for parties to react and new parties may need to be established and start winning elections before a substantial supply-side response is observed. In the British context, one could argue that it was not until the Labour Party became a threat to the Liberal Party in the first decade of the twentieth century that the supply-side response to the suffrage reforms 15-30 years earlier materialized.

It is not obvious which or which combination of these possibilities is the right one. Further work dealing with all of these problems would be valuable.

Supplementary Information The online version contains supplementary material available at https://doi. org/10.1007/s11698-021-00239-0.

Funding Keynes Fund (Cambridge).

\section{Declarations}

Conflicts of interest Data and code will be shared; no conflict of interests.

Open Access This article is licensed under a Creative Commons Attribution 4.0 International License, which permits use, sharing, adaptation, distribution and reproduction in any medium or format, as long as you give appropriate credit to the original author(s) and the source, provide a link to the Creative Commons licence, and indicate if changes were made. The images or other third party material in this article are included in the article's Creative Commons licence, unless indicated otherwise in a credit line to the material. If material is not included in the article's Creative Commons licence and your intended use is not permitted by statutory regulation or exceeds the permitted use, you will need to obtain permission directly from the copyright holder. To view a copy of this licence, visit http://creativecommons.org/licen ses/by/4.0/.

\section{References}

Acemoglu D, Naidu S, Restrepo P, Robinson J (2015) Democracy, redistribution, and inequality. Handb Income Distrib 2:1885-1966

Acemoglu D, Robinson J (2000) Why did the west extend the franchise? Democracy, inequality, and growth in historical perspective. Q J Econ 115(4):1167-1199

Aidt TS, Daunton M, Dutta J (2010) The retrenchment hypothesis and the extension of the franchise in England and Wales. Econ J 120(547):990-1020

Aidt TS, Dutta J, Loukoianova E (2006) Democracy comes to Europe: Franchise extension and fiscal outcomes, 1830-1938. Eur Econ Rev 50(2):249-283

Aidt TS, Jensen PS (2009a) Tax structure, size of government, and the extension of the voting franchise in Western Europe, 1860-1938. Int Tax Public Finance 16(3):362-394

Aidt TS, Jensen PS (2009b) The taxman tools up: an event history study of the introduction of the personal income tax. J Public Econ 93(1-2):160-175 
Aidt TS, Jensen PS (2013) Democratization and the size of government: evidence from the long 19th century. Public Choice 157:511-542

Aidt TS, Jensen PS (2017) From open to secret ballot: Vote buying and modernization. Comp Political Stud 50(5):555-593

Angrist J, Pischke J-S (2008) Mostly harmless econometrics: An empiricists companion. Princeton University Press, New Jersey

Atiyah PS (1979) The rise and fall of freedom of contract. Clarendon Press, Oxford

Aydelotte WO (1967) The country gentlemen and the repeal of the corn laws. Engl Hist Rev 82(322):47-60

Babbage C (1852) Thoughts on the principles of taxation with reference to a property tax and its exceptions (3rd, edition. John Murray, Albemarle Street, London

Blewett N (1965) The franchise in the United Kingdom 1885-1918. Past Present 32:27-56

Boix C (2001) Democracy, development, and the public sector. Am J Polit Sci 45(1):1-17

Boix C (2003) Democracy and redistribution. Cambridge University Press, Cambridge

Brock MG (1973) The Great Reform Act. Hutchinson University Library, London

Cannon JA (1973) Parliamentary reform, 1640-1832. Cambridge University Press, Cambridge, UK

Caramani D (2000) Elections in Western Europe since 1815. Electoral results by constituencies. Palgrave Macmillan Publishers Ltd., Basingstoke, Hampshire, UK

Cascio EU, Washington E (2014) Valuing the vote: The redistribution of voting rights and state funds following the Voting Rights Act of 1965. Q J Econ 129(1):379-433

Daunton M (2001) Trusting Leviathan: The Politics of Taxation in Britain, 1799-1914. Cambridge University Press, Cambridge, UK

Davis J (2000) Central government and the towns. In: Daunton M (ed) The Cambridge Urban History of Britain 1840-1950, Volume III of The Cambridge Urban History of Britain, Chapter 9. Cambridge University Press, Cambridge, UK, pp 261-286

Dickinson G (1895) The development of parliament during the 19th century. Longman Green and Co, London UK

Dorsch MT, Maarek P (2019) Democratization and the conditional dynamics of income distribution. Am Polit Sci Rev 113(2):385-404

Doyle BM (2000) The changing functions of urban government: Councillors, officials and pressure groups. In Daunton M (ed) The Cambridge Urban History of Britain 1840-1950, Volume III of The Cambridge Urban History of Britain, Chapter 10. Cambridge University Press, Cambridge, UK, pp 287-314

Eaglesham EJR (1967) The foundations of 20th-Century education in England. Routledge and Kegan Paul, Abingdon-on-Thames, UK

Evans EJ (2000) Parliamentary reform, 1770-1918. Pearson, London

Fitzgerald GAR (1876) The Ballot Act, 1872. Stevens and sons, London

Flora P, Alber J, Eichenberg R, Kohl J, Kraus F, Pfenning W, Kurt S (1983). State, economy and society in Western Europe 1815-1975, In: vol. I and II. Frankfurt, Germany: Campus Verlag

Harms P, Zink S (2003) Limits to redistribution in a democracy: A survey. Eur J Polit Econ 19(4):651-668

Hicks D (2013) War and the political zeitgeist: Evidence from the history of female suffrage. Eur J Polit Econ 31:60-81

Hoover K (1991) The causal direction between money and prices. An alternative approach. J Monetary Econ 27(3):381-423

Hoover K, Sheffrin S (1992) Causation, spending, and taxes: Sand in the sandbox or tax collector for the welfare state? Am Econ Rev 82(1):225-248

Hoover K, Siegler M (2000) Taxing and spending in the long view: The causal structure of us fiscal policy, 1791-1913. Oxford Econ Papers 52(4):745-773

Hoover KD (2001) Causality in macroeconomics. Cambridge University Press, Cambridge UK

Husted TA, Kenny LW (1997) The effect of the expansion of the voting franchise on the size of government. J Polit Econ 105(1):54-82

Keir DL (1953) The constitutional history of modern Britain, 1485-1951 (5th, edition). A and C, Black, London

Keith-Lucas B (1952) The English local government Franchise. Basil Blackwell, Oxford

Keith-Lucas B (1977) English Local Government in the 19th and 20th Centuries. General Series 90. The Historical Association, London

Kenny L, Winer S (2006) Tax systems in the world: An empirical investigation into the importance of tax bases, administration costs, scale and political regime. Int Tax Public Financ 13(2-3):181-215 
Kim W (2007) Social insurance expansion and political regime dynamics in Europe, 1880-1945. Soc Sci Q 88(2):494-514

Lindert P (1994) The rise of social spending, 1880-1930. Explor Econ Hist 31(1):1-37

Lindert PH (2004a) Growing public. Social spending and economic growth since the eighteenth century. Vol I: The story. Cambridge University Press, Cambridge UK

Lindert PH (2004b) Growing public. Social spending and economic growth since the eighteenth century. Vol II: Further evidence. Cambridge University Press, Cambridge UK

Maddison A (2003) The world economy: Historical statistics. OECD, Paris

Mares I, Queralt D (2015) The non-democratic origins of income taxation. Comp Polit Stud 48(14):1974-2009

Meltzer A, Richard S (1981) A rational theory of the size of government. J Polit Econ 89(5):914-927

Millward R (2000) The political economy of urban utilities. In: Daunton M (ed) The Cambridge Urban History of Britain 1840-1950, Volume III of The Cambridge Urban History of Britain, Chapter 11. Cambridge University Press, Cambridge, UK, pp 315-350

Mitchell B, Deane P (1962) Abstract of British historical statistics. Cambridge University Press, Cambridge, UK

Mood A, Graybill F (1963) Introduction to the Theory of Statistics (Second Edition ed.). McGraw-Hill Series in Probability and Statistics. New York: McGraw-Hill Book Company, Inc

Neftci S, Sargent TJ (1987) A little bit of evidence on the natural rate hypothesis from the U.S. J Monetary Econ 4:315-320

Peters G (1991) The politics of taxation. A comparative perspective, Basil Blackwell, Oxford, UK

Profeta P, Puglisi R, Scabrosetti S (2013) Does democracy affect taxation and government spending? Evidence from developing countries. J Comp Econ 41(3):684-718

Redlich J, Hirst FW (1958) The history of local government in England. MacMillan and co, London

Sabine BEF (1966) A history of income tax. George Allen \& Unwin, London

Scheve K, Stasavage D (2016) Taxing the rich: a history of fiscal fairness in the United States and Europe. Princeton University Press, Princeton, US

Schonhardt-Bailey C (2006) From the Corn Laws to free trade: interests, ideas and institutions in historical perspective. MIT Press, Cambridge, MA

Seligman ERA (1911) The income tax. Macmillan, London

Simon HA, Iwasaki Y (1988) Causal ordering, comparative statics, and near decomposability. J Econom 39:149-73

Smellie KB (1946) A history of local government. Allen and Unwin, London, London

Smith FB (1966) The making of the Second Reform Bill. Cambridge University Press, Cambridge, UK

Szreter S (1988) The importance of social intervention in Britains mortality decline 1850-1914: A reinterpretation of the role of public health. Soc Hist Med 1:1-37

Turner JD, Zhan W (2012) Property rights and competing for the affections of demos: the impact of the 1867 Reform Act on stock prices. Public Choice 150(3):609-631

Vine JS (1878) The municipal corporations. Waterlow and Sons Limited, London

Vine JS (1882) The English municipal code. Waterlow Bros and Layton, London

Waller PJ (1983) Town, City and Nation, England 1850-1914. Oxford University Press, Oxford, UK

Winer SL (2019) The political economy of taxation: Power, structure, redistribution. In: Congleton BGR, Voigt S (eds) The Oxford Handbook of Public Choice, Volume 2, Chapter 24. Oxford University Press, Oxford, UK

Publisher's Note Springer Nature remains neutral with regard to jurisdictional claims in published maps and institutional affiliations. 


\section{Authors and Affiliations}

\section{Toke S. Aidt ${ }^{1,2}\left(\mathbb{1} \cdot\right.$ Stanley L. Winer ${ }^{2,3}(\mathbb{D}) \cdot$ Peng Zhang ${ }^{4}$}

Stanley L. Winer

stanley.winer@carleton.ca

Peng Zhang

pza25@sfu.ca

1 Faculty of Economics, University of Cambridge, Austin Robinson Building, Sidgwick Avenue, CB3 9DD Cambridge, UK

2 CESifo, Munich, Germany

3 School of Public Policy and Administration and Department of Economics, Carleton University, Ottawa, Canada

4 Beedie School of Business, Simon Fraser University, Vancouver, BC, Canada 